\title{
Influences of wind and sandblasting on the endangered blowout penstemon
}

\author{
James Stubbendieck, Cheryl D. Schmidt*, Heidi L. Hillhouse, L. M. Landholt \\ Department of Agronomy and Horticulture, University of Nebraska, Lincoln, Nebraska 68583-0915, USA
}

\begin{abstract}
Blowout penstemon Penstemon haydenii is a federally endangered species growing only in areas with active wind erosion in sand dunes of the central United States. This early seral species declines as the blowout habitat stabilizes, allowing later seral species to increase. Blowout penstemon populations and plant size declined in the 1990s when precipitation was higher than normal, resulting in reduced sand movement. We conducted a greenhouse experiment to determine whether blowing sand influenced vigor and persistence of blowout penstemon seedlings. Treatments were wind, sandblasting, wind with sandblasting, and a control. The wind treatment was a constant $14 \mathrm{~km}$ $\mathrm{h}^{-1}$ from electric fans for $18 \mathrm{~h}$ daily. Sand was applied at $96 \mathrm{~km} \mathrm{~h}^{-1}$ weekly for 10 min to individual plants for the sandblasting treatment, and the wind with sandblasting treatment was a combination of both. Number of leaf pairs, height, and stem diameter were measured biweekly. Biomass was determined at the conclusion of each experiment. Both wind and sandblasting affected plant growth. The combination of wind with sandblasting increased plant height and stem diameter in Year 1, and stem diameter and shoot biomass in Year 2. This study supports field observations that blowout penstemon has a positive thigmomorphogenic response to wind and sandblasting. Less sand movement is associated with wet soils. Therefore, loss of mechanical stimuli could have been one of the reasons for population decline in the 1990s. Disturbance may be necessary to maintain the blowout habitat and provide an important stimulus to the blowout penstemon plants.
\end{abstract}

KEY WORDS: Blowout penstemon - Penstemon haydenii - Thigmomorphogensis - Wind . Sandblasting Resale or republication not permitted without written consent of the publisher

\section{INTRODUCTION}

Blowout penstemon Penstemon haydenii S. Watson (Fig. 1) is a forb native to the Nebraska Sandhills in the central United States, first collected in 1857 but not described until 1891 (Sutherland 1988). It is a semievergreen producing new shoots from buds near the base of the stems and has a life span of 4 to $8 \mathrm{yr}$ (Stubbendieck et al. 2007). Blowout penstemon typically flowers in the second or third year after establishment. Reproduction is from seeds, and the seedling stage is the most vulnerable part of its life cycle (US Fish and Wildlife Service 1987, Kottas 2008). In some years, seedlings do not establish (Stubbendieck 1986). Blowout penstemon was considered to be common in blowouts in 1913 (Pool 1914), but by 1940 it was thought to be extinct (Stubbendieck 1986). Rediscovered in 1968, it has been collected in 6 Nebraska counties (Sutherland 1988) and 1 Wyoming county (Heidel 2005). The number of plants in all populations was $2100 \pm 200 \mathrm{SD}$ in 1982, prompting blowout penstemon to be classified as federally endangered (US Fish and Wildlife Service 1987).

Blowouts, the habitat of this species, are sites of active wind erosion and are usually conical depressions on the top of sand dunes formed by the removal of sand by wind (Pool 1914, Stubbendieck et al. 1989). The above-ground biomass of the native prairie plant community must be severely reduced by grazing, fire, or other disturbance before wind can make contact with the sand to initiate a blowout (Stubbendieck et al. 1989). Once the vegetation is reduced, wind cuts into 


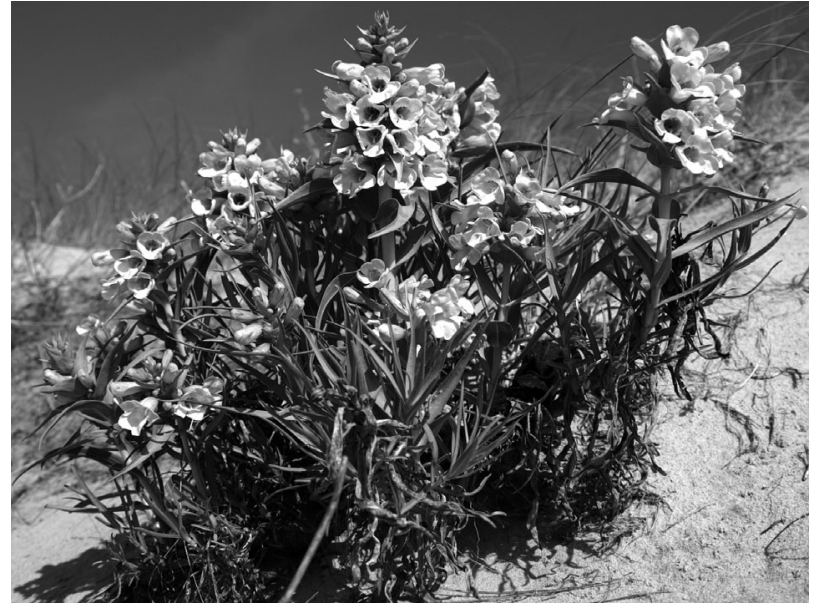

Fig. 1. Penstemon haydenii. Blowout penstemon

the dune removing the sand grains and blowing them up and over the rim of the blowout to an area of deposition. Blowouts move slowly across the landscape at a rate of 1 to $5 \mathrm{~m} \mathrm{yr}^{-1}$ (Stubbendieck et al. 1989).

An active blowout provides a harsh environment for plants. The first species to inhabit blowouts are often referred to as pioneer species and include blowoutgrass Redfieldia flexuosa (Thurb.) Vasey, lemon scurfpea Psoralidium tenuiflorum (Pursh) Rydb., James clammyweed Polanisia jamesii (Torr. \& A. Gray) Iltis, and blowout penstemon (Pool 1914, Stubbendieck et al. 1989). Sandhill muhly Muhlenbergia pungens Thurb. ex A. Gray succeeds these pioneer species. Neither blowoutgrass nor blowout penstemon can persist in the sandhill muhly stage of succession (Tolstead 1942). Constant wind erosion is required for persistence of blowout penstemon (Stubbendieck et al. 1989).

The most important factor influencing the decline in blowout penstemon since 1914 is loss of habitat caused by control of wildfires and changes in land management (Stubbendieck et al. 1989). Private land owners improved grassland conditions by limiting improper use by livestock through the application of planned grazing systems that coupled appropriate stocking levels with techniques designed to evenly distribute grazing animals. They eliminated many blowouts by mechanically shaping the sharp edges, seeding, and fencing out livestock until the more grazing-appropriate prairie vegetation established. These actions greatly reduced the number and average size of blowouts which are a prerequisite for the recruitment and continued survival of blowout penstemon. Relatively small, isolated concentrations of blowouts are all that remain of the once common complexes of blowouts throughout much of the Nebraska Sandhills (Fritz 1998).

Abnormal climatic conditions influence most prairie species (Weaver 1956). The drought of the 1930s was the most notable climatic event between the time when blowout penstemon was common in blowouts and when it was thought to be extinct, but the impact of the drought on the species is unknown. However, numbers of plants in most populations of blowout penstemon did not decline during the recent 2000 to 2006 drought (J. Stubbendieck unpubl. data). We recorded an average decline of $9 \%$ in blowout penstemon populations during a period of relatively moist years in the 1990s (J. Stubbendieck unpubl. data). These declines were not associated with competition from other plant species. Instead, blowout penstemon plants weakened and died within a few years for no immediately apparent reason. During the 1990s, more frequent precipitation kept the surface sand moist for greater periods of time, and as wet sand is not moved by wind it is hypothesized that the decline in blowout penstemon populations was associated with reduced wind erosion.

Influence of wind or windblown sand has been documented for many field crops (e.g. cotton Gossypium spp., winter wheat Triticum aestivum, grain sorghum Sorghum bicolor, maize Zea mays, kidney beans Phaseolus vulgaris, sunflower Helianthus annuus) (Armbrust 1968, Cleugh et al. 1998, Baker 2007), vegetables (e.g. tomato Lycopersicon esculentum) (Armbrust et al. 1969), and coastal dune plant species (e.g. common bugseed Corispermum hyssopifolium, seaside spurge Euphorbia polygonifolia, American searocket Cakile edentula, amberique-bean Strophostyles helvola, white sweetclover Melilotus alba, rough cocklebur Xanthium strumarium, Canada wildrye Elymus canadensis, Canada bluesgrass Poa compressa, sanddune wheatgrass Agropyron psammophilum, switchgrass Panicum virgatum, prairie sandreed Calamovilfa longifolia, Ammophila breviligulata, little bluestem Schizachyrium scoparium) (Maun \& Perumal 1999, Martínez et al. 2001, Ogura \& Yura 2008). Thigmomorphogenesis, or plant growth response to mechanical stimuli, such as wind or windblown sand (Jaffe 1973), has been demonstrated to result in plants with shorter height, decreased leaf area, increased stem width, and increased root:shoot ratio (Whitehead \& Luti 1962). Plant species, length of exposure, plant height, and age when exposed can cause variations in thigmomorphogenesis (Armbrust 1968, Grace 1977, Retuerto \& Woodwardt 2001, Baker 2007). Coupled with changes in plant morphology, physiological characteristics affected include decreased photosynthesis, increased respiration, reduced transpiration, and an increased ability to resist damage by pests (Whitehead \& Luti 1962, Cipollini 1997).

Variations in sand movement influenced plant distribution and succession in coastal sand dunes in Mexico (Martínez et al. 2001). Early colonizers were positively correlated to sand movement, exhibiting increased 
growth rate and leaf area, while late colonizers were negatively correlated with respect to these traits. However, no known study has assessed these factors on plant species associated with blowouts in the central United States.

Based on the blowout penstemon population trends in the 1990s, we hypothesized that blowing sand was important for the species' vigor and persistence. In a preliminary study, we transplanted greenhouse-grown seedlings in late spring into several blowouts in the Nebraska Sandhills and evaluated the transplants 4 mo later. Blowout shape and orientation resulted in areas of uneven wind velocity in different parts of the blowout, as evidenced by variable wind erosion (J. Stubbendieck unpubl. data). Plants exposed to more wind and blowing sand during the summer months averaged $35 \mathrm{~cm}$ in height and had 4.5 vegetative shoots. However, plants growing in areas in the same blowouts that were protected from the action of the wind averaged $9 \mathrm{~cm}$ in height and had 1.1 vegetative shoots. We designed and conducted a greenhouse experiment to determine whether wind and windblown sand influence the growth of blowout penstemon. We chose to evaluate these influences on seedlings, because this stage has been shown to be the most vulnerable in the species' life cycle (Kottas 2008). Our results may help to explain why blowout penstemon declined during periods of above average precipitation, and may provide support for the development of management strategies for this federally endangered species.

\section{MATERIALS AND METHODS}

Experimental design. In 2004 and 2005, seeds of blowout penstemon Penstemon haydenii were harvested and grown in a greenhouse following techniques developed by Stubbendieck et al. (2007). Seedlings were started in flats and, when they had reached a height of 1 to $3 \mathrm{~cm}$ above the cotyledonary node and had 3 or 4 pairs of true leaves, plants were transplanted into individual $15 \times 15 \mathrm{~cm}$ green plastic pots filled with pasteurized sand after approx. $6 \mathrm{wk}$. Two weeks following transplanting, 96 uniform plants were placed in a randomized complete block design with 4 blocks ( 24 plants per block, 6 plants per treatment) to test the effects of wind and sandblasting on plant growth. Blocking was used to address potential greenhouse temperature and light variations. Treatments were (1) control, (2) wind, (3) sandblasting, and (4) wind with sandblasting.

An open-topped Plexiglas ${ }^{\circledR}$ box (1.5 m long, $0.9 \mathrm{~m}$ wide, and $0.8 \mathrm{~m}$ high) was placed on each bench to restrict wind movement between treatments. The front of each box with the wind treatments was left open to allow for the placement of a fan, while the back of the box was closed to support the sides and direct the wind upward and away from other plants in the greenhouse. Twelve evenly spaced marks were placed on the bench within each box to delineate pot placement. The initial placement of pots within each box was random. Density of plants equaled average density of plants occurring naturally in the field. A mark was placed on each pot as a reference point, and the pots were moved systematically and rotated $90^{\circ}$ every $4 \mathrm{~d}$.

Plants in the control were not exposed to wind or sandblasting. The wind treatment was $14 \mathrm{~km} \mathrm{~h}^{-1}$ of constant wind from electric fans for $18 \mathrm{~h}$ daily to approximate the average wind movement in the Nebraska Sandhills (NOAA 2009). The sandblasting treatment consisted of sand applied at $96 \mathrm{~km} \mathrm{~h}^{-1}$ to individual plants for $10 \mathrm{~min}$ on $1 \mathrm{~d} \mathrm{wk}^{-1}$ for $16 \mathrm{wk}$. This wind speed was necessary to maintain sand particles in suspension, and gusts of 90 to $100 \mathrm{~km} \mathrm{~h}^{-1}$ are not uncommon in the Nebraska Sandhills (NOAA, www. ncdc.noaa.gov). For the sandblasting treatment, plants were removed from the boxes, treated individually, and returned to the boxes. The wind with sandblasting treatment was a combination of both treatments.

Measurements. Plants were measured immediately prior to treatment and then once every $2 \mathrm{wk}$. Data recorded were number of leaf pairs, height, and stem diameter. Height was measured from the point of attachment of the cotyledonary leaves to the extended tip of the uppermost leaf. Stem diameter was measured with a caliper at the midpoint between the points of attachment of the cotyledonary leaves and the first pair of true leaves.

Biomass was measured at the conclusion of the experiment from 1 plant from each treatment in each block in Year 1 and 2 plants in Year 2. Plants were harvested at the soil surface. Root samples were washed from the sand. Root and shoot samples were weighed following drying in a forced air oven at $35^{\circ} \mathrm{C}$ until moisture loss was complete.

Statistical analysis. Freshly harvested seeds were used for seedling production each year. Dry conditions during seed development in Year 2 resulted in seeds $30 \%$ lighter than the seeds used in Year 1. Initial measurements were significantly different between years (Table 1), and an F-test indicated unequal variances

Table 1. Penstemon haydenii. Mean starting measurements of seedlings $( \pm \mathrm{SE})$ from Year 1 and Year 2

\begin{tabular}{|cccc|}
\hline & $\begin{array}{c}\text { Height } \\
(\mathrm{mm})\end{array}$ & $\begin{array}{c}\text { Stem diameter } \\
(\mathrm{mm})\end{array}$ & $\begin{array}{c}\text { Number of leaf } \\
\text { pairs }\end{array}$ \\
\hline Year 1 & $30.3(0.8)$ & $1.09(0.02)$ & $5.4(0.08)$ \\
Year 2 & $19.4(0.6)$ & $0.99(0.02)$ & $4.4(0.05)$ \\
\hline
\end{tabular}


between treatment years. Therefore, data were separated by year, and a multiple analysis of variance (MANOVA) was used to determine whether treatment influenced the change in growth parameters. When significant differences were detected, the MANOVA was followed by a Tukey HSD (Honestly Significant Difference) test. Because of unequal variences, a Kruskal-Wallis test (Zar 1999) was used to assess the influence of treatment on the shoot, root, and root:shoot biomass. A non-parametric Tukey's test (Zar 1999) was performed when differences were detected. To determine whether treatment significantly influenced biweekly measurements of height, a repeatedmeasures analysis of variance (ANOVA) with between-subjects factors was used for each year followed by a Tukey HSD (within-subject variable: weeks; between-subject variable: treatment). Statistical analyses were performed using SPSS (version 17.0). Statistical significance level was $\leq 0.05$.

\section{RESULTS}

\section{Year 1}

Treatments caused differences in growth parameters (number of leaf pairs: $F=3.246, \mathrm{p}=0.026$; height: $F=$ 3.496, $\mathrm{p}=0.019$; stem width: $F=5.840, \mathrm{p}=0.001)$. In comparison to the control, the wind with sandblasting treatment increased stem height $(p=0.034)$ and stem diameter ( $p=0.016$ ) (Table 2$)$. The wind with sandblasting treatment resulted in more leaf pairs than the sandblasting treatment alone $(\mathrm{p}=0.034)$. Plants subjected to wind with sandblasting were taller $(p=0.036)$ and had wider stems $(p=0.005)$ than plants in the wind treatment (Table 2). Shoot, root, and root:shoot biomass were not different between treatments $(H=$ 1.654, $\mathrm{p}=0.80 ; H=0.221, \mathrm{p}=0.99 ; H=2.85, \mathrm{p}=0.58$, respectively).

The repeated-measures ANOVA with between-subjects factor showed a significant linear difference between the interaction of time and treatment $(F=4.924$, $\mathrm{p}=0.003$ ). Sandblasting and the combination of wind with sandblasting resulted in greater plant height than the control ( $p=0.045$ and 0.018, respectively) (Fig 2).

\section{Year 2}

Stem diameter differed between treatments $(F=$ $6.699, \mathrm{p}<0.001)$. Stem diameter was greater with the combined wind with sandblasting treatment in comparison to the control ( $p=0.001)$ and to the sandblasting treatment alone $(\mathrm{p}=0.001)$ (Table 3$)$. Shoot biomass was different between the treatments $(H=$ $10.049, \mathrm{p}=0.039)$. The wind with sandblasting treatment resulted in higher shoot biomass $(p \leq 0.05)$ in comparison to the control (Table 3 ). Treatments did not influence root biomass $(H=3.73, \mathrm{p}=0.49)$ or root: shoot biomass $(H=1.593, \mathrm{p}=0.81)$.

Table 2. Penstemon haydenii. Year 1 means $( \pm \mathrm{SE})$ of the change in response variables (final minus initial) with treatments. Significant differences $(\mathrm{p} \leq 0.05)$ between treatments indicated by the post-hoc tests are represented by different superscript letters within columns

\begin{tabular}{|llccccc|}
\hline Treatment & Leaf pairs & $\begin{array}{c}\text { Height } \\
(\mathrm{mm})\end{array}$ & $\begin{array}{c}\text { Stem diameter } \\
(\mathrm{mm})\end{array}$ & $\begin{array}{c}\text { Shoot } \\
\text { biomass }(\mathrm{g})\end{array}$ & $\begin{array}{c}\text { Root } \\
\text { biomass }(\mathrm{g})\end{array}$ & $\begin{array}{c}\text { Root: } \\
\text { shoot ratio }\end{array}$ \\
\hline Control & $11.41^{\mathrm{ab}}(0.47)$ & $128.32^{\mathrm{a}}(7.40)$ & $2.179^{\mathrm{a}}(0.122)$ & $0.779^{\mathrm{a}}(0.265)$ & $1.096^{\mathrm{a}}(0.477)$ & $1.229^{\mathrm{a}}(0.220)$ \\
Sandblasting & $10.54^{\mathrm{a}}(0.39)$ & $146.96^{\mathrm{ab}}(8.20)$ & $2.597^{\mathrm{ab}}(0.114)$ & $1.148^{\mathrm{a}}(0.287)$ & $1.407^{\mathrm{a}}(0.079)$ & $1.418^{\mathrm{a}}(0.300)$ \\
Wind & $10.87^{\mathrm{ab}}(0.46)$ & $129.13^{\mathrm{a}}(10.63)$ & $2.117^{\mathrm{a}}(0.139)$ & $0.893^{\mathrm{a}}(0.101)$ & $1.328^{\mathrm{a}}(0.324)$ & $1.418^{\mathrm{a}}(0.212)$ \\
Wind with & $12.29^{\mathrm{b}}(0.41)$ & $165.71^{\mathrm{b}}(10.98)$ & $2.714^{\mathrm{b}}(0.119)$ & $0.778^{\mathrm{a}}(0.071)$ & $1.478^{\mathrm{a}}(0.230)$ & $1.961^{\mathrm{a}}(0.363)$ \\
sandblasting & & & & & & \\
\hline
\end{tabular}

Table 3. Penstemon haydenii. Year 2 means $( \pm$ SE) of the change in response variables (final minus initial) with treatments. Significant differences $(\mathrm{p} \leq 0.05)$ between treatments indicated by the post-hoc tests are represented by different superscript letters within columns

\begin{tabular}{|lcccccc|}
\hline Treatment & Leaf pairs & $\begin{array}{c}\text { Height } \\
(\mathrm{mm})\end{array}$ & $\begin{array}{c}\text { Stem diameter } \\
(\mathrm{mm})\end{array}$ & $\begin{array}{c}\text { Shoot } \\
\text { biomass }(\mathrm{g})\end{array}$ & $\begin{array}{c}\text { Root } \\
\text { biomass (g) }\end{array}$ & $\begin{array}{c}\text { Root: } \\
\text { shoot ratio }\end{array}$ \\
\hline Control & $7.58^{\mathrm{a}}(0.42)$ & $87.04^{\mathrm{a}}(6.20)$ & $1.199^{\mathrm{a}}(0.061)$ & $0.556^{\mathrm{a}}(0.064)$ & $1.295^{\mathrm{a}}(0.315)$ & $2.223^{\mathrm{a}}(0.362)$ \\
Sandblasting & $8.29^{\mathrm{a}}(0.58)$ & $103.63^{\mathrm{a}}(7.99)$ & $1.199^{\mathrm{a}}(0.070)$ & $0.700^{\mathrm{ab}}(0.084)$ & $1.109^{\mathrm{a}}(0.122)$ & $1.683^{\mathrm{a}}(0.152)$ \\
Wind & $7.88^{\mathrm{a}}(0.48)$ & $91.79^{\mathrm{a}}(7.85)$ & $1.386^{\mathrm{ab}}(0.066)$ & $0.814^{\mathrm{ab}}(0.089)$ & $1.587^{\mathrm{a}}(0.377)$ & $1.749^{\mathrm{a}}(0.231)$ \\
Wind with & $7.91^{\mathrm{a}}(0.38)$ & $92.70^{\mathrm{a}}(6.52)$ & $1.573^{\mathrm{b}}(0.077)$ & $0.892^{\mathrm{b}}(0.086)$ & $1.868^{\mathrm{a}}(0.301)$ & $1.984^{\mathrm{a}}(0.191)$ \\
sandblasting & & & & & & \\
\hline
\end{tabular}


No significant differences were revealed by the repeated-measures ANOVA with between-subjects factor (Wilks' lambda $=1.277, \mathrm{p}=0.180$ ) (Fig. 3).

\section{DISCUSSION}

Wind and/or windblown sand have been hypothesized as being important abiotic components that shape community composition on sand dunes (Maun \& Perumal 1999, Martínez et al. 2001, Ogura \& Yura 2008). Many pioneer species in a sand dune community are tolerant to sand movement, and their growth and vigor are even stimulated by it (Maun 1994, Martínez \& Moreno-Cassola 1996, Maun 1998, Martínez et al. 2001). This is consistent with our findings and field observations that the federally endangered blowout penstemon Penstemon

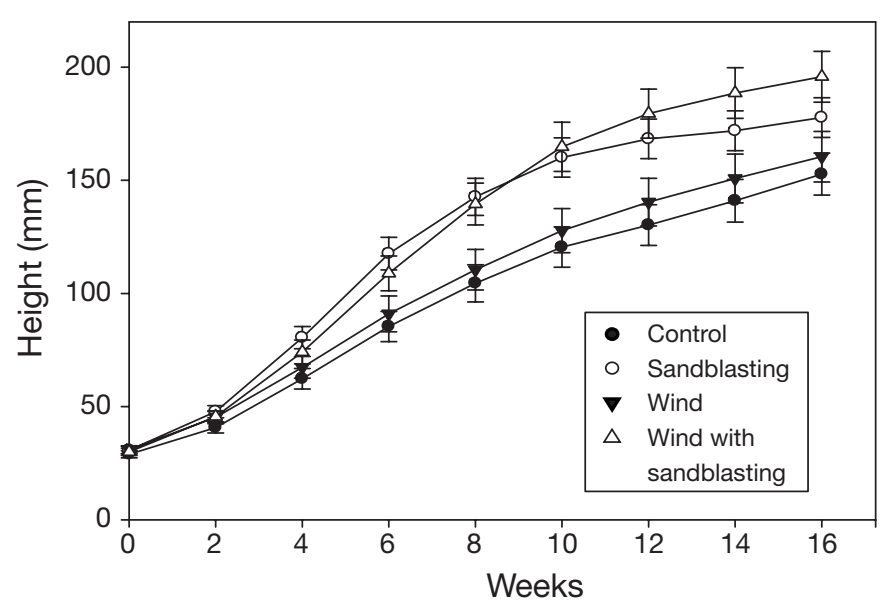

Fig. 2. Penstemon haydenii. Year 1 mean height $(\mathrm{mm}) \pm \mathrm{SE}$ of blowout penstemon over 16 wk with differing treatments: control, sandblasting, wind, and wind with sandblasting

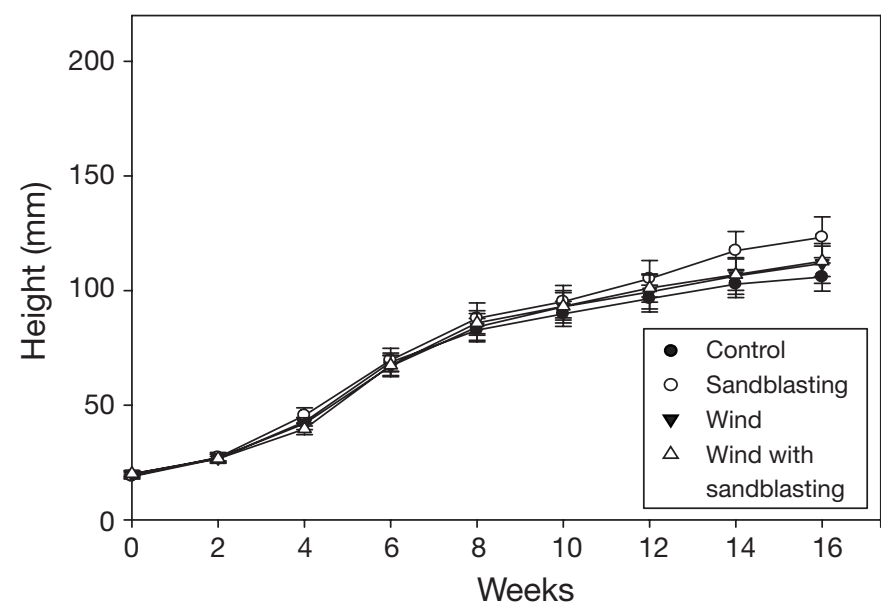

Fig. 3. Penstemon haydenii. Year 2 mean height $(\mathrm{mm}) \pm \mathrm{SE}$ of blowout penstemon over 16 wk with differing treatments: control, sandblasting, wind, and wind with sandblasting haydenii tolerates sand movement and may exhibit a positive thigmomorphogenic response to wind and sandblasting. The overall trend was an increase in plant height (Figs. $2 \& 3$ ) and stem width with exposure to wind with sandblasting. In Year 1, plant height was significantly greater with the sandblasting and wind with sandblasting treatments than the control (Fig. 2). Biweekly plant height increased an average of $28 \%$ compared to a $24 \%$ increase for blowout penstemon plants not exposed to a treatment. A similar response was exhibited by some early colonizers in coastal sand dunes in Mexico (Martínez et al. 2001). However, these results contradict other studies on other species which determined that plant height decreased in response to touch (Whitehead and Luti 1962, Grace 1977).

Stem width of blowout penstemon increased in both years with the combination treatment of wind with sandblasting. One hypothesis is that some plants have evolved highly responsive mechanisms to thigmomorphogensis. Touch stimulates the expression of several genes, which produces proteins encoding for stem cell wall modification (Chehab \& Braam 2009). The differing results between years are likely related to unequal initial plant size. Plant age and size have been shown to cause differing levels of response to a mechanical stimulus (Armbrust 1968, Latimer 1991).

Biomass increased, but not significantly, in response to wind with sandblasting. Shoot mass was approx. $61 \%$ higher with the combination of wind and sandblasting in Year 2 in comparison to the control. Increased sample size in Year 2 helped to reduce the variability recorded in Year 1. These results support the findings of Armbrust (1968) that low levels of mechanical stimuli, in the form of soil or sand movement, may stimulate growth of seedlings.

Root:shoot biomass ratios indicate that the young plants were partitioning more resources to root growth. Although not significant, the root:shoot ratio tended to increase in Year 1 and decrease in Year 2 with the addition of wind, sandblasting, and the combination of wind with sandblasting. Root:shoot ratio increases have been reported by others, but the response was dependent on plant age in relation to sandblasting and was coupled with a significant loss of shoot mass (Whitehead \& Luti 1962, Cleugh et al. 1998). Loss of shoot mass did not occur in our study. An increase in root mass may allow the plant to maintain an adequate water balance. With other plant species, transpiration rates initially increased with wind and sandblasting until there was a sufficient loss of shoot mass to cause transpiration rates to decrease (Whitehead 1962, Whitehead \& Luti 1962). Mechanical stimuli may be important for increasing growth, thus allowing blowout penstemon to flourish in the harsh blowout environment. 
Blowout penstemon did not respond negatively to wind and/or windblown sand. In general, positive growth responses to the combination of wind with sandblasting were greater than to wind alone. These results support field observations that blowout penstemon has less vigorous growth when sand movement is reduced. Once late seral stage species begin to establish, the blowout begins to stabilize, and blowout penstemon declines (Stubbendieck et al. 1989). Therefore, competition may not be the only driving force behind blowout penstemon decline during natural succession. Loss of mechanical stimuli may have been one of the causes of decline in blowout penstemon during the 1990s. More frequent precipitation kept the surface of the sand damp for longer periods, thus decreasing sand movement. In the early 20th century and before, wildfires were common in the Nebraska Sandhills and helped to create and maintain habitat for blowout penstemon. Fire is no longer a viable option in the region because a fire that is out of control can cover hundreds of $\mathrm{km}^{2}$ before reaching a firebreak, and legally required burning permits are rarely issued.

Selecting sites with active sand movement for restoration of this endangered species may be critical for its survival. Disturbance will be necessary to maintain the blowout habitat and may provide an important stimulus to the blowout penstemon plants. Hoof action of grazing cattle helps to loosen the sand allowing it to be more easily transported by the wind. Maintaining active wind erosion by mechanical disturbances such as disking or rototilling are other options that should be considered in the management and conservation of existing populations of blowout penstemon.

\section{LITERATURE CITED}

Armbrust DV (1968) Windblown soil abrasive injury to cotton plants. Agron J 60:622-625

Armbrust DV, Dickerson JD, Greig JK (1969) Effect of soil moisture on the recovery of sandblasted tomato seedlings. J Am Soc Hortic Sci 94:214-217

Baker JT (2007) Cotton seedling abrasion and recovery from wind blown sand. Agron J 99:556-561

Chehab EW, Braam EE (2008) Thigmomorphogensis: a complex plant response to mechano-stimulation. J Exp Bot 60:43-56

Cipollini DF (1997) Wind-induced mechanical stimulation increases pest resistance in common bean. Oecologia 111:84-90

> Cleugh HA, Miller JA, Böhm M (1998) Direct mechanical effects of wind on crops. Agrofor Syst 41:85-112

Fritz MI (1998) Research on the effects of grazing and mechanical disturbances on blowout penstemon (Penstemon haydenii), Final Report. US Fish and Wildlife Service, Grand Island, NE

Grace J (1977) Plant response to wind. Academic Press, London

Editorial responsibility: Dave Roberts,

Kew, UK
Heidel B (2005) Survey of Penstemon haydenii (blowout penstemon) in Wyoming. University of Wyoming, Laramie, WY

Jaffe MJ (1973) Thigmomorphogensis: the response of plant growth and development to mechanical stimulation. Planta 114:143-157

Kottas KL (2008) Life history and modeling of an endangered plant, Penstemon haydenii. PhD dissertation, University of Nebraska, Lincoln, NE

Latimer JG (1991) Mechanical conditioning for control of growth and quality of vegetable transplants. Hortscience 26:1456-1461

Martínez ML, Moreno-Cassola P (1996) Effects of burial by sand on seedling growth and survival of six tropical sand dune species. J Coast Res 12:406-409

> Martínez ML, Vázquez G, Colón SS (2001) Spatial and temporal variability during primary succession on tropical coastal sand dunes. J Veg Sci 12:361-372

Maun MA (1994) Adaptations enhancing survival and establishment of seedlings on coastal dune systems. Vegetatio 111:59-70

> Maun MA (1998) Adaptations of plants to burial in coastal sand dunes. Can J Bot 76:713-738

Maun MA, Perumal J (1999) Zonation of vegetation on lacustrine coastal dunes: effects of burial by sand. Ecol Lett 2:14-18

> Ogura A, Yura H (2008) Effects of sandblasting and salt spray on inland plants transplanted to coastal sand dunes. Ecol Res 23:107-112

Pool RJ (1914) A study of the vegetation of the Sandhills of Nebraska. Minn Bot Stud IV:190-312

Retuerto R, Woodwardt FI (2001) Compensatory responses in growth and fecundity traits of Sinapis alba L. following release from wind and density stress. Int J Plant Sci 162:171-179

Stubbendieck J (1986) Blowout penstemon; The Sandhills' rare jewel. Inst Agr Nat Resour, University of Nebraska, Lincoln, NE

Stubbendieck J, Flessner TR, Weedon RR (1989) Blowouts in the Nebraska Sandhills: the habitat of Penstemon haydenii. In: Bragg T, Stubbendieck J (eds) Proc N Am Prairie Conf, University of Nebraska, Lincoln, NE p 223-225

Stubbendieck J, Kottas KL, Fitzgerald JB (2007) Transplanted seedlings enhance populations of endangered blowout penstemon (Nebraska). Ecol Res 25:225-226

Sutherland D (1988) Historical notes on collections and taxonomy of Penstemon haydenii S. Wats (blowout penstemon), Nebraska's only endemic plant species. Trans Nebr Acad Sci XVI:191-194

Tolstead WL (1942) Vegetation of the northern part of Cherry County, Nebraska. Ecol Monogr 12:255-292

US Fish and Wildlife Service (1987) Final rule to determine Penstemon haydenii (Blowout penstemon) to be an endangered species. Fed Regist 52:32926-32929

Weaver JE (1956) North American prairie. Johnsen Publishing Co., Lincoln, NE

Whitehead FH (1962) Experimental studies of the effect of wind on plant growth and anatomy. II. Helianthus annuus. New Phytol 61:59-62

Whitehead FH, Luti R (1962) Experimental studies of the effect of wind on plant growth and anatomy I. Zea mays. New Phytol 61:56-58

Zar JH (1999) Biostatistical analysis. Prentice-Hall, Upper Saddle River, NJ

Submitted: July 20, 2009; Accepted: October 18, 2009

Proofs received from author(s): December 22, 2009 